
A. García-Quintana
J. F. Martín-Duque
J. A. González-Martín
J. F. García-Hidalgo
J. Pedraza
P. Herranz
R. Rincón
H. Estévez

\section{Geology and rural landscapes in central Spain (Guadalajara, Castilla_La Mancha)}

A. García-Quintana · R. Rincón

H. Estévez

Dpto. Estratigrafía, Inst. Geol. Económica, Fac. C.C. Geológicas, U.C.M, 28040

Madrid, Spain

J. F. Martín-Duque · J. Pedraza

Dpto. Geodinámica, Fac. C.C. Geológicas, U.C.M, 28040 Madrid, Spain

J. A. González-Martín

Dpto. Geografía, Fac. Filosofía y Letras, Univ. Autónoma de Madrid, 2849

Madrid, Spain

J. F. García-Hidalgo ( $\square)$

Dpto. Geología, Fac. C.C. Ambientales, Univ. de Alcalá, 28871 Alcalá de Henares, Spain

E-mail: jose.garciahidalgo@uah.es

Tel.: + 34-918855097

Fax: + 34-918855090

P. Herranz

Dpto. Correlaciones, Inst. Geol.

Económica, Fac. C.C. Geológicas,

CSIC-UCM, 28040 Madrid, Spain

\begin{abstract}
Methods commonly used in regional geological analysis were employed to study the visual landscapes of the Sigüenza Molina de Aragón area (Spain). Landscape data were compiled to produce a landscape map and a photograph catalogue. Lithological composition, tectonic structure and recent erosive processes are the main factors controlling the visual landscapes. Territorial properties, such as colours and agricultural capacities, are controlled by these geological characteristics. The landscape map and the photographic catalogue is the main contribution of this paper. The first level of landscape classification distinguishes zones with dominance of either flat, concave or convex areas. Other parts of the territory are, however, composed of concave and convex combinations that originate hybrid orographic structures. In a second level of classification, several subdivisions for each of these types are established.
\end{abstract}

Keywords Rural landscapes · Landscape map · Spain

\section{Introduction}

The landscape is an important environmental resource, and one of growing cultural, social and economic value. It is the most easily recognizable attribute of the environment, particularly when considered as scenery (Moss and Nickling 1980). In this sense, a territory becomes a landscape when it is expressed in terms of physiographical or environmental features (Laurie 1975).

Most of the territory of the Mediterranean region has a rural character. Rural spaces show a great variety of landscapes, their main attraction residing in the balance between their ecological, historic-cultural and aesthetic components. These landscapes have mainly been subject 
to traditional agricultural uses (livestock and forestry), the most important modifications being ahnost exclusively restricted to the transformation or removal of the plant cover. The impact of construction is scarce, and usually in agreement with the environment. Where small modifications of the relief have been made, these have generally blended into the environment over time.

Social dynamics and economic development, however, have made 'extreme conservation' unfeasible for the entirety of these landscapes. Further, landscapes are dynamic, and concern for their protection should be focused on adequate management rather than on the 'static safeguards' often proposed. Not all rural landscapes are affected by the infrastructures of developed societies, but corrective measures can improve areas that have suffered important visual deterioration.

The conservation, management and recovery of rural landscapes in the Mediterranean region requires specific legal support. But for this to be possible, detailed and accurate knowledge about the types of landscape present, their distribution, composition and value must be available. It is in these aspects that landscape management and protection are at their weakest. As the landscape has been one of the most recent natural components to be incorporated into our culture, concern over its conservation has preceded an understanding of it, and landscapes that are inadequately understood can hardly be adequately protected. In fact, landscapes are frequently poorly defined: a precise definition of 'landscape units' is still required (Fairbanks and Benn 2000).

There is a considerable difference of opinion surrounding the concept of landscape and this has led to an absence of standardization in analytical methodologies

Fig. 1 Location of the study area. Crossed Hesperian Massif, a Hercynian basement partially reactivated during the Alpine orogeny (e.g. The Central System); bricks Alpine Ranges, mainly Mesozoic calcareous sediments, including Hercynian basement elements and small Tertiary basins (e.g. the Teruel Basin); white post-Alpine Cenozic basins, mainly clay sediments, in the older areas including some minor Alpine units (e.g. the Altomira Mountains). The study area is shown on the right
(Terkenli 2001). Until recently, literature that investigates the use of geology in the management of rural landscapes is scarce, despite the fact that geological materials are the basis of all natural resources, and that within any natural system the only certain, independent shaping agents are climate, time and geology (Al Bakri 2001; Garcia-Quintana et al. 2004). As biophysical attributes, such as soil, water, fauna and flora, are either directly or indirectly influenced by these shaping agents, they must be considered dependent factors (effects) ( $\mathrm{Al}$ Bakri 2001). Geology is the most important shaping agent that influences the intrinsic characteristics of all dependent factors: climate has an important effect at the inter-regional level but has limited influence on small areas within a climatic zone, time tends to be directly reflected in geological units (Al Bakri 2001), and even topographic characteristics that cause local climatic variations are controlled primarily by an area's geology (Garcia-Quintana et al. 2004).

In regions where the climate is not particularly wet (e.g. in the Mediterranean region), the primary physical framework of the landscape is relief. Relief is a succession and overlapping of topographic forms of many types and sizes, far from the simple, homogeneous surface appreciated in topographic maps and DTMs (even though such maps can be expressed mathematically, treated digitally and represented graphically). Relief, the basis of rural landscapes, is a consequence of regional geological history and of recent processes. The configuration of the relief can be analysed in terms of three major variables that, although interrelated, tend to overlap in time: the lithological and stratigraphic pattern of the territory, the tectonic structure of the rocks and the type and intensity of erosive processes (Bloom 1969; Wright 1972; Burbank and Printer 1999; Garcia-Quintana et al. 2004).

This paper deals with the classification and mapping of rural landscapes in an area of the centre of the Iberian Peninsula, the Sigüenza Molina de Aragón region (Fig. 1). This classification is based on geological factors, which control the physiography of the entire
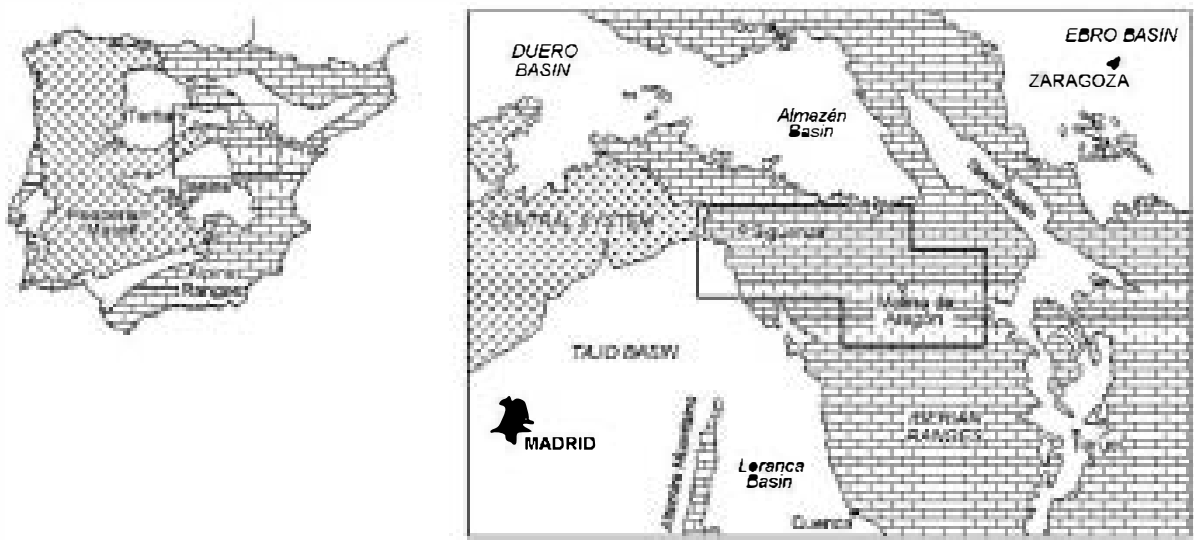
territory. The area has a high diversity of landscapes in a reasonably good state of preservation, a fact owed to a combination of natural and socioeconomic factors (the latter more conditioned by the former than vice versa). From this landscape classification, a landscape map and a catalogue of landscape types were produced. Comparison of the landscape map with current geological and topographical maps establishes their similarities and differences.

\section{Earlier investigations}

It is widely recognized that landscape classifications should be based on the intrinsic characteristics of landforms (Wright 1972). Attempts to define geomorphological regions began around the end of the nineteenth century with the work of G. M. Wheeler, C. King and J. W. Powell in the USA, the emphasis of which was mainly physiographical (e.g. Powell 1875; King 1878; Wheeler 1889). These initial studies culminated in that of Fenneman (1916), who divided the USA into physiographical regions according to surface configurations based on the progressive subdivision of the continent.

During the first half of the twentieth century, the need for detailed territorial classification led to intensive surveys in several countries. In Great Britain, Bourne (1931) showed the need to divide the surface of the Earth into natural regions of uniform character. This author also suggested the use of aerial photographs and geological maps. Linton (1951) recognized the value of morphological units in defining regional patterns. In Australia, the emphasis of the CSIRO land research division focused on land systems and units (Christian 1958). The former are a group of closely related topographic units that emerge as a common geomorphic phenomenon, and are appropriate for $1: 1, \mathbf{0 0 0 , 0 0 0}$ to $1: 250,000$ scale mapping. In the former Soviet Union, a similar analytical method was developed based on morphological units that repeat in regular patterns (Nikolayev 1973).

More recently, two approaches to classification and landscape mapping have been used. The first is a mainly physiographical approach based on the work of authors such as Godfrey (1977) who, working in the USA, proposed a physiographical classification for territorial planning. This approach divides territories into smaller and smaller units, so that each detailed level incorporates the criteria of the most general levels. This plan, based on physiography and topography, was followed in Australia by authors such as Pain (1985) who based their work on Landsat imagery, and by Guzzetti and Reichenbach (1994) who used digital terrain models (DTMs). The second approach takes into account vegetation and establishes phyto-geomorphic (Howard and
Mitchell 1980) and ecological classifications or "ecoregions' (Omernik 1987; Bailey 1996). However, much landscape ecology research investigating the problems of biological conservation is not based on properly defined landscapes but on arbitrarily defined ecoregions (Host et al. 1996). The distribution of plants is controlled by physical and biological variables, and some authors have concluded that topographic (physiographical or structural) and climatic elements should lie at the base of landscape classification (Fairbanks and Benn 2000).

In Spain, landscape mapping has either relied on ecological classifications (Martin de Agar et al. 1995; Gómez de Mendoza et al. 1999) or has been limited to recording the geometric properties of visual spaces (Barettino and Gallego 1996; Martin Duque 1997). An exception is the physiographical map of Madrid (Pedraza et al. 1986). Converging with the American physiographical school, but with the limitations of its $1: 2 \mathbf{0 0 , 0 0 0}$ scale, this is an approximation to landscape mapping.

\section{Studied area}

The Sigüenza Molina de Aragón region lies at the centre of the Iberian Peninsula, in the north of the Iberian Range (Fig. 1) and at a mean altitude slightly above $1,000 \mathrm{~m}$. The climate is temperate Mediterranean, somewhat modified by continental conditions and by altitude. The mean annual temperature is $910^{\circ} \dot{\mathrm{C}}$. Winters include very cold periods (the Molina observatory registered one of the lowest temperatures ever recorded in Spain: $-28^{\circ} \mathrm{C}$ ), while summers are warm. Rainfall is moderate (about $600 \mathrm{~mm}$ per year).

This region has one of the lowest population densities in Spain, with inhabitants concentrated in the main towns of Sigüenza (population 5,000) and Molina de Aragón (population 4,000). Of medieval origin, these centres are in depressions or valleys, and so reduced has been their development that only recently have these towns expanded beyond their city walls. The remaining villages in the area are small and practically depopulated in winter, and have only small holiday populations even in summer. Industry is ahnost non-existent; services have been little developed in line with regional demand. The primary sector is limited to the cultivation of one quarter of the area's land surface (Estébanez et al. 1991), stock raising (now in decline) and a little (almost nonexistent) forestry. Communications are, as a rule, small and poor, and do not stand out visually. The exceptions are the Alcolea del Pinar sector and the Henares and Jalón valleys, which are crossed by the major Madrid Zaragoza A-2 highway, a railway and a high-speed railway. However, the rugged nature of the landscape partly diminishes the impact of these infrastructures. Further, as some of their length is limited to particular 
visual areas and as environmental legislation (though admittedly lax) has been adhered to, their visual impact is reduced. The territory clearly has a low environmental impact index, only lately threatened by the installation of wind farms.

The area's recent history is reflected in its landscapes and its present level of development. The relatively high population of the Middle and Modern Ages gave rise to the intensive use of cultivatable land (fertile valleys and shallow slopes on less cohesive rocks). Strong deforestation caused by grazing on many of the higher areas and cohesive rock-covered areas also occurred. However, over the last few decades, rural emigration, the use of new fuels (the butane cylinder), interest in the environment and the interests of economic institutions, have all favoured an increase in the amount of plant cover.

\section{Geological factors in Molina-Sigïenza landscapes}

Climate, stratigraphic-structural composition and orographic configuration of the region condition the anthropic uses that can be made of it, and together, these four factors determine its landscapes. Geological factors, as stated above, lie in the base for landscape classification.

\section{Recent geomorphic processes}

Neogene and Quaternary erosive episodes originate the present orography of the studied area. The most outstanding orographic components of the region are the plateaux ('parameras'), plains and low-relief surfaces between $900 \mathrm{~m}$ and 1,100 m (Fig. 2). Minor reliefs (up to $1,3 \mathbf{0 0} \mathrm{m}$ ) of limited extent also occur. There is only one upland area reaching $1,500 \mathrm{~m}$ (the Sierra de Aragoncillo). They correspond to Neogene planation surfaces and their residual reliefs (Hercynian and Buntsandstein outcrops).
The second structure, which appears geometrically superimposed on the previous one, is an irregular and discontinuous network of dendritic-trending valleys generated during fluvial entrenchment $150 \mathrm{~m}$ on average) in the Quaternary. The fluvial network largely belongs to the appropriately named Tagus or 'Gorge' river.

Besides these major morphological structures, there are smaller orographic features which, as discussed later, are interrelated with the typology, the development of plant cover and agriculture. These factors are neither appreciable in topographical maps (Fig. 2) nor in DTMs (Fig. 3) which provide a more panoramic view of the territory. From the point of view of the landscape, these are more apparent than real.

\section{Stratigraphic and tectonic structure}

The lithological composition and tectonic structure of this region are also important factors in the natural environment. Both control the properties of the territory, such as its colour and agricultural capacity. This is of the highest importance in the landscapes of this area, as the distributions of the different plant covers are clearly related to the ploughability of the soil.

The studied area is composed of three major geological units (Fig. 4): (a) Hercynian basement rocks, mainly made up of shales and quartzites that crops out at the core of the de Aragoncillo and Menera Mountains; (b) Mesozoic Paleogene rocks, which are folded and faulted and (c) horizontal Neogene rocks.

The Mesozoic strata, which forms most of the territory, is composed of an alternation of cohesive (hard) and less cohesive (less resistant) bodies (lithostratigraphic units). The cohesive and permeable rock units are the basal Jurassic dolostones (Cortes de Tajuña Fm. and other related units), the calcareous units of the Lower and Middle Jurassic age (Barahona Fm. and other related units), and Upper Cretaceous dolostones and limestones (Villa de Vés Fm.). The Permian and
Fig. 2 Topographic map of study area based on the 1:50,000 DTM of the National Geographic Institute. Contour lines $100 \mathrm{~m}$ apart. The area is composed of large bigh plateaux $(1,0001,250 \mathrm{~m})$ long mountain ranges (but small in total area) that stand out on the plains $(1,2501,550 \mathrm{~m}$, e.g. between El Pobo and Maranchón), and a fluvial network entrenchment (e.g. NW of Mihnarcos, W of Molina de Aragón)

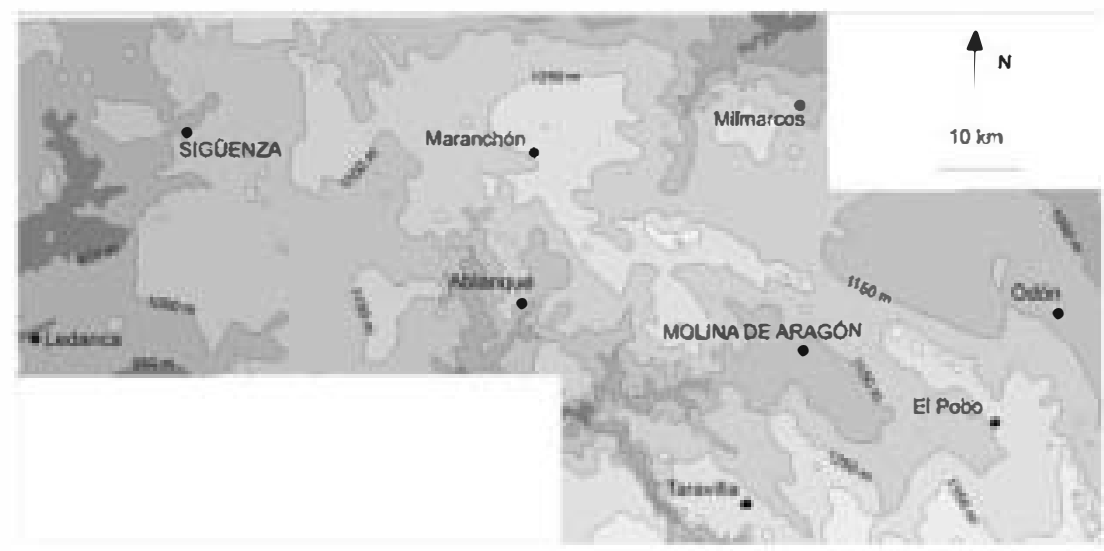


Fig. 3 3-D digital elevation model of the study area based on the $1: 50,000$ DTM of the National Geographic Institute. This map shows, from a different perspective, the same data as in Fig. 2, but in a more aestheric and less precise way

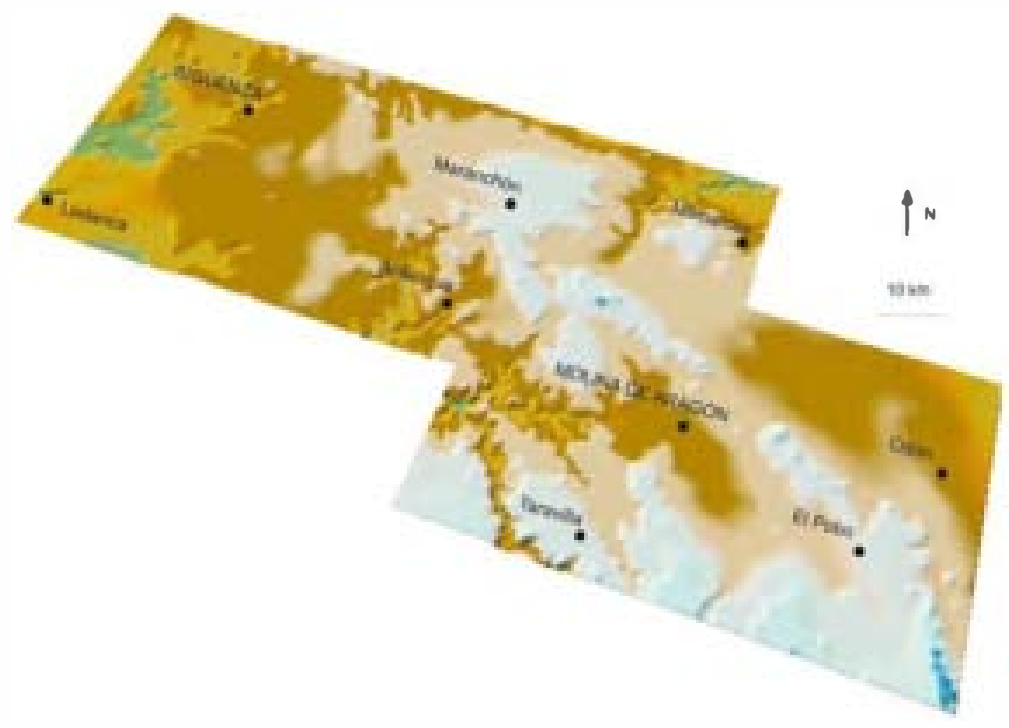

Lower Triassic shales and sandstones (Ermita Beds, Montesoro Beds, Hoz del Gallo Conglomerates and other units of the Buntsandstein facies) represent somewhat less consistent and less permeable rock units. Separating these four cohesive units are three less cohesive units which can sustain agriculture. The two older ones, the Upper Triassic clays (Keuper facies) and the Lower Jurassic marls (Turmiel Marls and other

Fig. 4 Geological map of the study area a synthesis of the 1:50,000 sheets of the geological map of Spain (Geological Survey of Spain). The more outstanding geological features of the central and western parts of the Iberian Range are well shown (see Fig. 1 for location). The main tectonic trend is NW SE, although in the intersection with the Central System, traverse structures also develop (e.g. in the Sigüenza area in the NW). This chain has a certain symmetry. Both Hercynian basement and the oldest rocks crop out in the central area, while modern rocks crop out toward the external areas units), are impermeable. The youngest unit, consisting of the Middle Cretaceous sands (Utrillas Sands and other units), is the most permeable.

The coloration of the landscape is controlled by the colour of these rock bodies, with minor differences depending on the type of plant cover and the season. The areas composed of Palaeozoic shales are largely given over to forestry. The coloration of these landscapes is either very stable (where there is a conifer cover) or highly variable (in areas with Quercus-oaks and related trees). They are also blackish owing to to the presence of shales. The territories composed of Triassic rocks have burgundy tones that emphasise the vegetation present at all times of year, as well as the use made of the soil. The territories composed of Jurassic and Cretaceous calcareous rocks have grey colours that mimic the vegetation in winter, but which are masked by this in summer. The territories composed of Middle

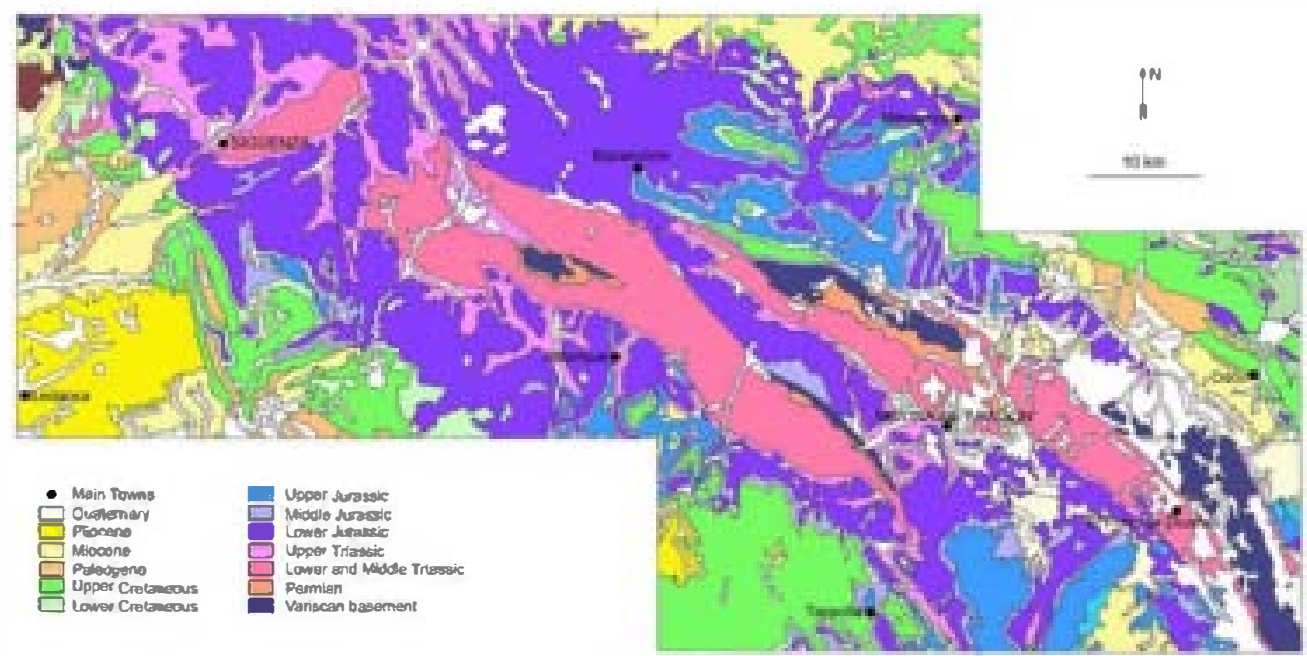


Cretaceous rocks can be quite covered by plants, but where there are steep slopes or where agriculture is practised there are striking and characteristic whitish areas. The territories composed of Tertiary sediments are those that best sustain agriculture. Their colours vary greatly according to the season, although intense yellows and oranges are very characteristic. On the plains of the Alcarria, the uppermost calcareous sediments have whitish tones, which turn red in areas with decalcified clays or 'terras rossas'.

The Alpine tectonic structure that affects the Mesozoic and Palaeogene rocks is not very complex. Nevertheless, it is sufficiently important to have placed rock units with different erosive properties at the same height throughout the region (see above). Because of this, on plateaux and plains developed on these different rock bodies, there are great differences in the mechanical and hydrological properties influencing the development of the natural vegetation (or rather 'pseudo-natural' since it is always controlled, to a greater or lesser degree, by grazing, forestry and the intensity and type of agriculture practiced). The different landscapes along route $\mathrm{N}$ 211 between Alcoléa del Pinar and Molina de Aragón are a good example of this.

Such tectonic structure produces areas with different geometric distributions of rock bodies, e.g. sub-horizontal (north of Sigüenza), undulated (east of Maranchón), inclined (north of Ablanque), folded (north of Milmarcos) and fractured distributions (west of Sigüenza). Many of the present visual spaces of these territories were created in the last two million years by fluvial erosion of the less cohesive rocks - more erodable by far than the cohesive rocks.

\section{Landscape and maps}

\section{Landscape concepts}

The making of a landscape map requires the naming and hierarchical classification of inherent landscape concepts. However, the ambiguity surrounding the concept of 'landscape' (Aoki 1999) - even if more dialectic than real (García-Quintana et al. 2004) - has not favoured attempts to map it. The production of landscape maps containing territorial and visual features requires the first methodological step of dividing the area. In geology, botany, agriculture, and so on, only those concepts that are clearly defined can be mapped.

One of the problems of extending landscape studies and of reporting methodologies and results is the confusion caused by the word 'landscape' being used for three different concepts. First, there is the 'territorial landscape', whose defining factor is homogeneity. For the definition of this, Sochava (1972) proposed the term 'geosystem' while Bertrand and Berutchachvili (1978) proposed 'geofacies'. These terms are used very little but perhaps ought to be given more importance. Secondly, there is the 'perceptual landscape' (a very much appreciated concept in the social sciences) in which personal factors (cultural, emotional, experimental, etc.) are more important than the physical make-up of the territory: this idea is, therefore, not discussed here. Thirdly, there is the 'visual landscape', probably the oldest concept and etymologically the most correct.

Once those three landscape concepts are clearly differentiated, two facts arise. The first is that the visual landscape has been much less scientifically studied (but not artistically), than the perceptual landscape and especially the territorial landscape. Secondly, very complex relationships exist among these three landscape concepts. For example, one area (territorial landscape) produces different images (visual landscape) when the observer's position changes, and also produces different sensations, when the own observer changes (perceptual landscape).

The main objective is to reach an integral concept of landscape (territorial visual perceptual). In some territories with very particular and specific properties, and whose images are very well known to have been widely shown, i.e. the Great Canyon or the Dolomites, it is easier to reach that integral concept of landscape. Then a basic idea can be inferred: all the images of a region or a concrete area contain a common essence of their landscape. This is the main concept of landscape upon which this work is based, but at smaller scales and for all the territory (Fig. 5). Then, the visual properties of any image and the view of a specific territory can thus be generalized, and the wide diversity of scenery in a territory traced in maps.

The practical need for simplicity in maps, and the geomorphic importance of the spatial relationships between land areas, justifies the definition of physiographical visual units within landscapes. These visual units are readily outlined in maps, and can be divided into smaller and more comprehensible units for use by the wider public, including planners and legislators. They are based on only a few characteristics and are easily memorized, keeping the number of landscape types to a minimum.

\section{Preparation of the landscape map}

In the present work, landscapes are considered as integrated physical systems, defining identifiable kilometricscale patterns. In the process of landscape classification, numerical and spatial analyses have been avoided, as it is intended that the outcome be understood by the widest possible range of users. 


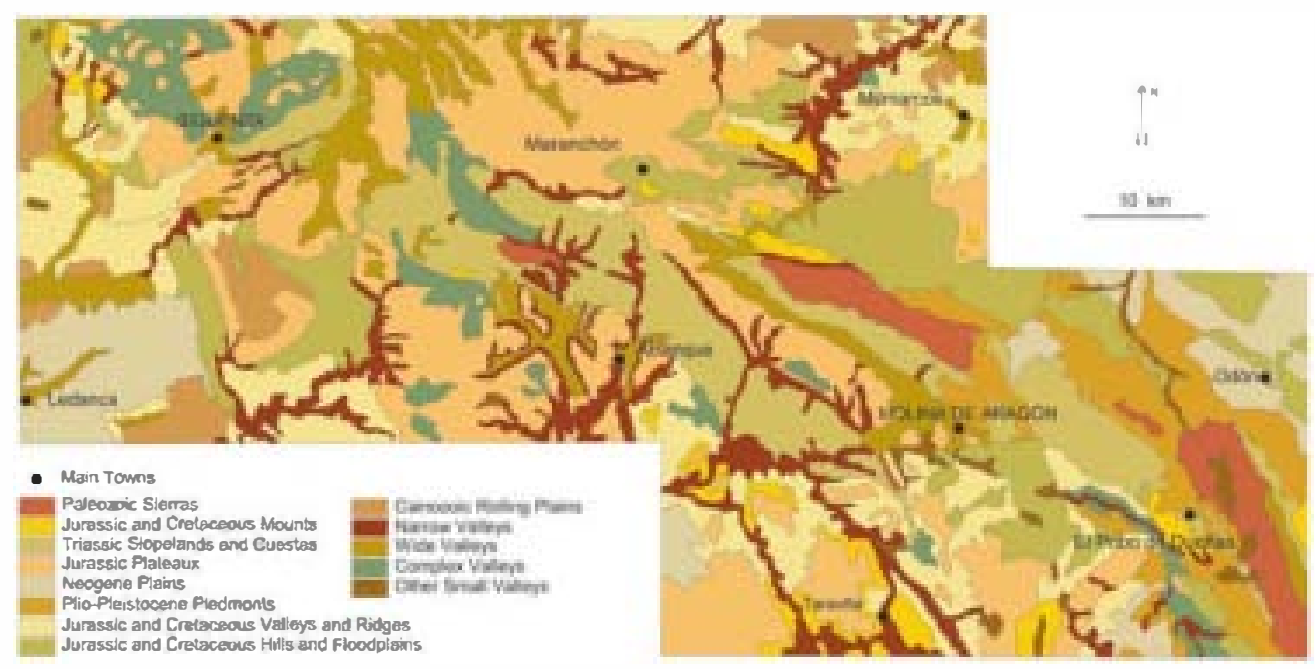

Fig. 5 Visual landscape map. The different defined categories have the same visual properies, although their geotic and biotic compositions could be different. This map, to a certain degree, shows the Neogene and Quaternary erosive episodes. The first is a mosaic of longer and rounded elements with an 'alveolar' structure. It coincidences with the geological map to a certain degree, because it partly corresponds to Neogene planation surfaces and their residual reliefs (Hercynian and Buntsandstein outcrops). The second structure, which appears geometrically superimposed on the previous one, is an irregular and discontinuous network of dendritic-rending valleys and other fluvial landscapes generated during fluvial entrenchment in the Quaternary

For the production of the present landscape map, three simultaneous approaches were undertaken. The first was based on geological knowledge of the region, mainly provided by a geological cartographic database ( 9 sheets of the 1:50,000 geological map of Spain). Secondly, aerial photographs of this region were studied in detail to recognize and define the boundaries of the landscape units. Aerial images are practical and appropriate for examining wide areas of territory, although the information on plant cover, tectonic structure, the geomorphological forms of erosion, etc., are always subordinate to visual criteria. Finally, fieldwork and traditional ground photographs provided data for comparison with the results of the above methods.

The landscape map obtained (Fig. 5) has a different structure from all other geographic and thematic maps of the region (Figs. 2, 3, 4). However, it has the appearance of being the 'sum' of the features shown in these other maps (type of plant cover, structure and geological composition, type and distribution of geomorphological surfaces and features). This is logical as these properties of the territory are mutually related, and are emphasized in rural landscapes through traditional agricultural activity. In some respects, the landscape map more closely resembles the topographic map of the area, while in others it is more similar to the geological or geomorphological map. This shows the importance of the different constituents of landscape scenery. As a

whole, the landscape structure map is most similar to the geological map (Figs. 4, 5).

This classification is also practical and functional as resource from different social and economic point of views, because visual landscape units are easily understood by planners and citizens. The organization of geological landscapes from a visual point of view can be used directly in the following areas:

1. Environmental management, to identify and recognize the natural patrimony, to negotiate the uses of the territory and to develop politics of preservation of natural areas.

2. Educational policy, to increase the understanding and appreciation of the territory, and to promote more and better activities in nature.

3. Economic strategy, to facilitate the uses and sustainable development of the territory, and even to promote natural and cultural tourism.

Besides, for environmental impact assessment, the detailed and exact knowledge of visual landscapes based in their geological factors, in many cases, can help to better characterize the natural sensitiveness and carrying capacity with respect of different kind of impacts.

\section{Configuration and classification of landscapes}

The first level of classification distinguishes the dominant areas-either flat, concave or convex forms (Table 1). Other parts of the territory are, however, composed of concave and convex combinations that produce hybrid orographic structures. The hybrid forms are almost always in an intermediate position, in terms of height and distance, between the flat and concave forms.

The surface and height distribution of relief is a function of the area's post-Alpine geological history, i.e. 
Table 1 Landscape types: main features and properties

\begin{tabular}{|c|c|c|c|c|c|}
\hline Landscape structure & Key landscape & Stratigraphy & Tectonic structure & Visual field & Observations \\
\hline \multicolumn{6}{|c|}{ Convex Forms: landscapes composed either of residual reliefs on Neogene planation surfaces, or originated by exhumation of pre-Miocene reliefs } \\
\hline Paleozoic Sierras & Sierra Menera & Palaeozoic & Hercynian & Great regional element & Forestry or rocky textures \\
\hline Jurassic and Cretaceous mounts & Tartanedo & Cretaceous & Sub-horizontal & Regional focal element & Agricultural on natural terraces \\
\hline Triassic Slopelands and Cuestas & Aragoncillo & Muschelkalk & Inclined & Regional visual limit & $\begin{array}{l}\text { Causes dissymmetry } \\
\text { in agricultural use }\end{array}$ \\
\hline \multicolumn{6}{|c|}{ Flat forms: landscapes inherited from Neogene and Quaternary planation surfaces, barely or not degraded by Plio- Quaternary erosion } \\
\hline Jurassic Plateaux & Maranchón & Jurassic & Undulated & Wide and homogeneous & Deforestation by grazing \\
\hline Neogene plains & Ledanca & Miocene & Horizontal & Wide and heterogeneous & Extensive cereal crops \\
\hline Plio-Pleistocene Piedmonts & Rampa de Coso (Molina) & Pliocene & $\begin{array}{l}\text { Sub-horizontal- } \\
\text { Sedimentary slope }\end{array}$ & Wide and inclined & Extensive cereal crops \\
\hline \multicolumn{6}{|c|}{ Concave forms: landscapes produced by post-Pliocene fluvial network entrenchment } \\
\hline Narrow valleys & Gallo river (Ventosa) & Buntsandstein & Inclined & $\begin{array}{l}\text { Narrow, defined } \\
\text { and intricate }\end{array}$ & No agrarian use \\
\hline Wide valleys & Dulce river (Pelegrina) & Keuper and Jurassic & Horizontal & $\begin{array}{l}\text { Wide, defined } \\
\text { and simple }\end{array}$ & $\begin{array}{l}\text { Extensive crops } \\
\text { and forestry on slopes }\end{array}$ \\
\hline Complex valleys & $\begin{array}{l}\text { Vadillo and Vaderas river } \\
\text { plains (Palazuelos) }\end{array}$ & Keuper and Jurassic & Horizontal & $\begin{array}{l}\text { Wide, undefined } \\
\text { and complex }\end{array}$ & $\begin{array}{l}\text { Extensive crops } \\
\text { and pastures on hills }\end{array}$ \\
\hline Other small valleys & $\begin{array}{l}\text { Several (ravines, } \\
\text { dolines, etc.) }\end{array}$ & All & Any type & $\begin{array}{l}\text { Small and bighly } \\
\text { variable }\end{array}$ & $\begin{array}{l}\text { In large view, either irrelevant } \\
\text { if isolated or forming textural } \\
\text { elements if common }\end{array}$ \\
\hline \multicolumn{6}{|c|}{ Hybrid forms: landscapes in development and spatial transition from plains to valleys (forms traditionally not considered by geomorphologists) } \\
\hline $\begin{array}{l}\text { Jurassic and Cretaceous ridges } \\
\text { and valleys }\end{array}$ & Fuente del Tejar (Judes) & Jurassic & Folded and faulted & $\begin{array}{l}\text { Narrow, concrete } \\
\text { and intricate }\end{array}$ & $\begin{array}{l}\text { Rocks, spontaneous vegetation } \\
\text { and forestry uses }\end{array}$ \\
\hline $\begin{array}{l}\text { Jurassic and Cretaceous bills } \\
\text { and floodplains }\end{array}$ & Vegas de Cecas (Amayas) & Jurassic & Undulated & Wide and complex & $\begin{array}{l}\text { Extensive crops and pastures } \\
\text { on bills }\end{array}$ \\
\hline Cainozoic rolling plains & Masegoso & Miocene & Horizontal & Wide and dispersed & $\begin{array}{l}\text { Variety of crops and areas } \\
\text { with spontaneous vegetation }\end{array}$ \\
\hline
\end{tabular}


Fig. 6 Location map and $\bullet$ ientation of photographs in

Figs. 7, 8, 91 T॰wns; 2 Main villages; 3 Highways; 4 Main rads; 5 High speed railway; 6 Railways; 7 Community boundaries; 8 Bøundaries and numbers $\bullet$ the sheets from the Geøløgical Map of Spain; 9 Rivers; 10 Lecation and orien.

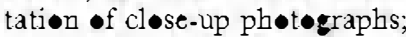
11 Location and orientation of

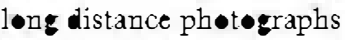

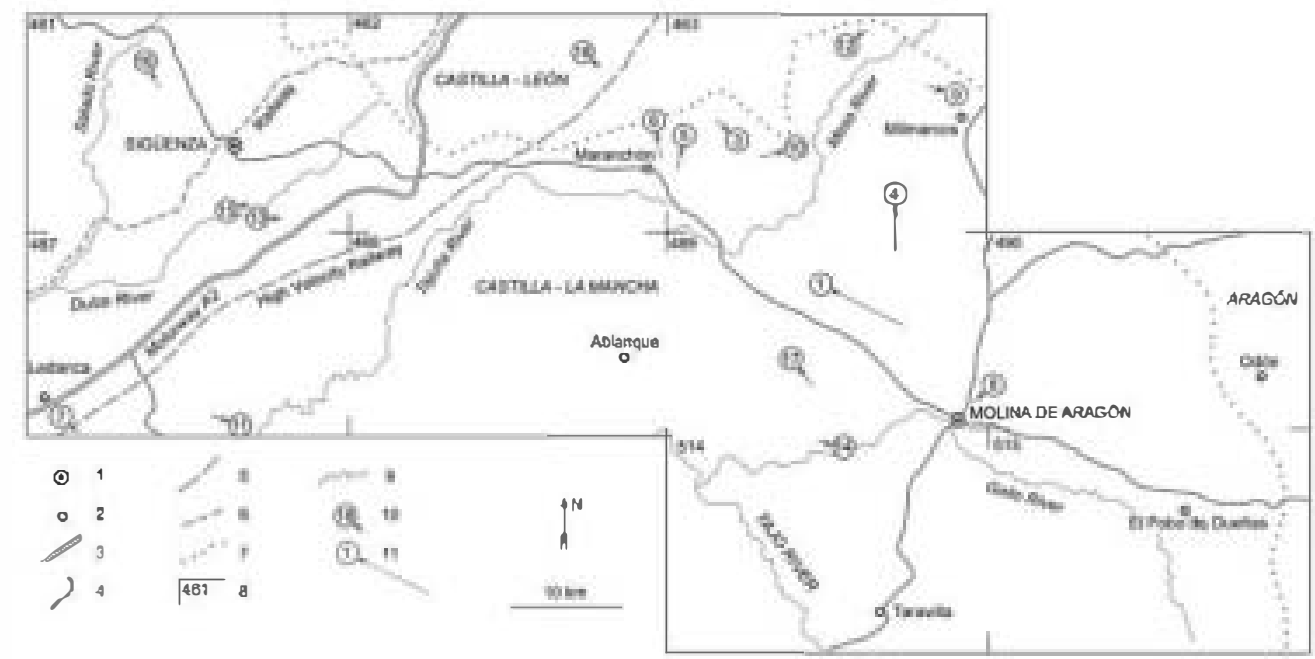

of the last 20 million years. At a more detailed classification level (see below), the stratigraphic and tectonic structures are major conditioners of orographic structure, and therefore of the area's agricultural uses and distribution of plant cover.

The geological factors are the most important in the configuration of the landscapes of this area, and condi- tion inter-related biotic and anthropic factors that can also be influential (although combinations of all these influences are never seen, at least at regional level). However, the concurrence of influences can be very similar in different areas of the region, leading to visually identical landscapes that are mapped as belonging to the same category. Thus, to produce a classification of re-
Fig. 7 Views of convex and flat landscapes described in text (see Fic. 6 for location and orienta-

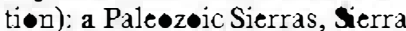
de Aragoncillø fr $\bullet$ Majadillas hichs (Pardes), view towards WNW. UTM 5814534; b Paleøzic Sierras, Sierra Menera frøm San Segund• hernitage (Hombrades), view towards SE. UTM 622-4510; c Triassic slopelands and cuestas, Campill $\bullet$ Cuesta fr $\bullet$ m C»des, view towards SE. UTM 574-4546; d Jurassic and Cretaceuus mounts, Cid Head

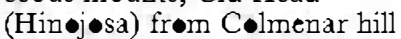
(Tartaned•), view towards N. UTM 590-4543; e Jurassic plateaux, Clares plateau from the Maranchon road, view towards NNE. UTM 570-4543; f Jurassic plateaux, Codes plateau from the Maranchon road, view towards NNW. UTM 571-4548
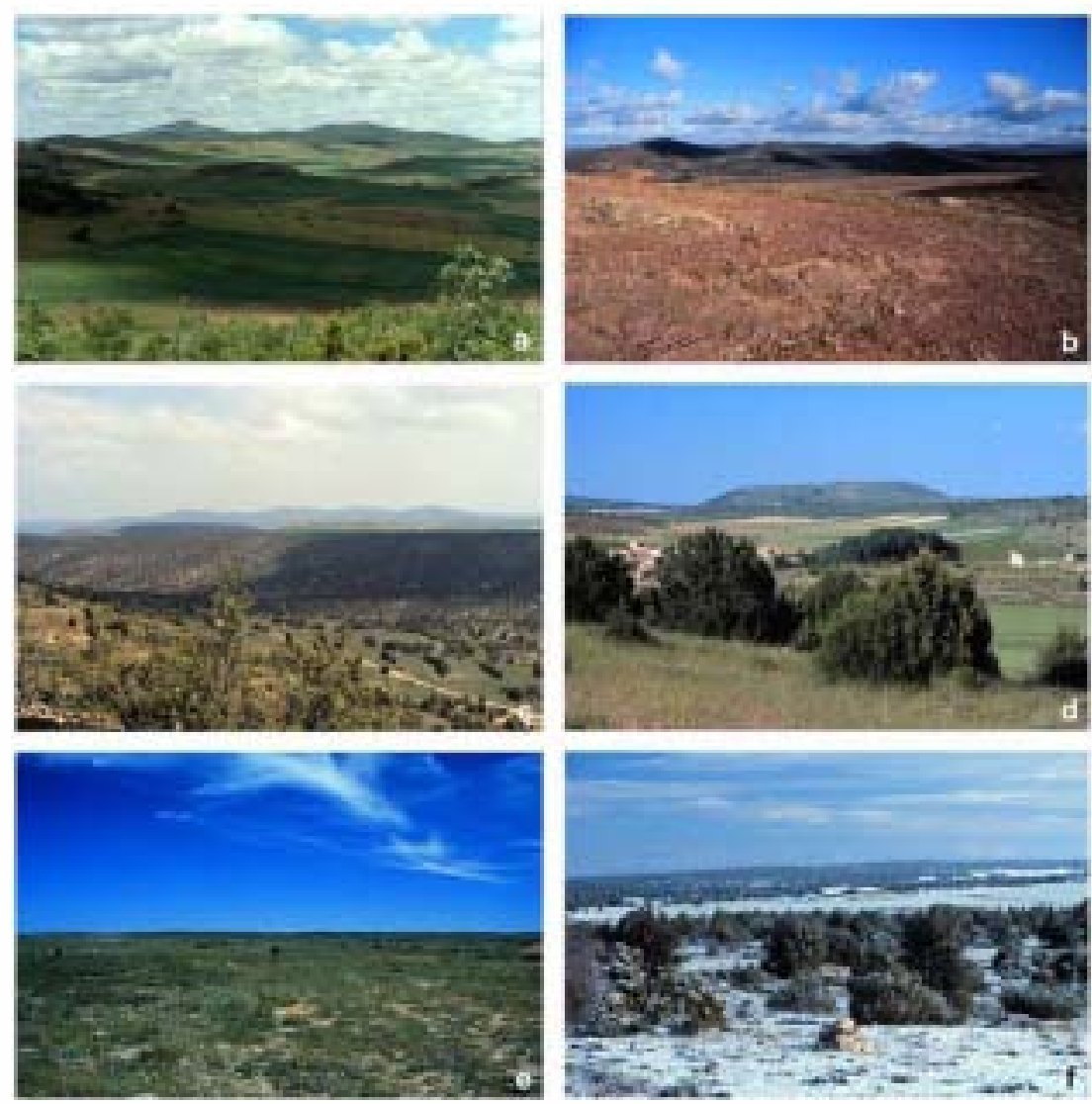
Fig. 8 Views of flat and hybrid landscapes described in text (see Fig. 6 for location and orientation): a Neogene plans, Navafría plain (La Alcarria, Ledanca), from the Navafría high-speed railway bridge towards NW. UTM 514-4522;

b Plio-Plestocene piedmonts, El Coso Ramp (Molina de Aragon) from the Rueda road towards the NE. UTM 596-4523; c Jurassic and Cretaceous ridges and valleys, the Castillejo bills from Navajo del Reconquillo (Mihnarcos), view towards ESE. UTM 596-4551; Jurassic and Cretaceous bills and floodplains, Vegas de Ceca from Malanquilla (Amayas), on the way to Anchuela del Campo, view towards ENE. UTM 584 4546; e Cainozoic rolling plains, Mesilla hills (Masegoso) from the Penado road, view towards ESE. UTM 524-4520; f Cainozoic rolling plains, Los Cabezos hills (Villel de Mesa) from the road to Los Corrales, view towards SW. UTM 583-4556
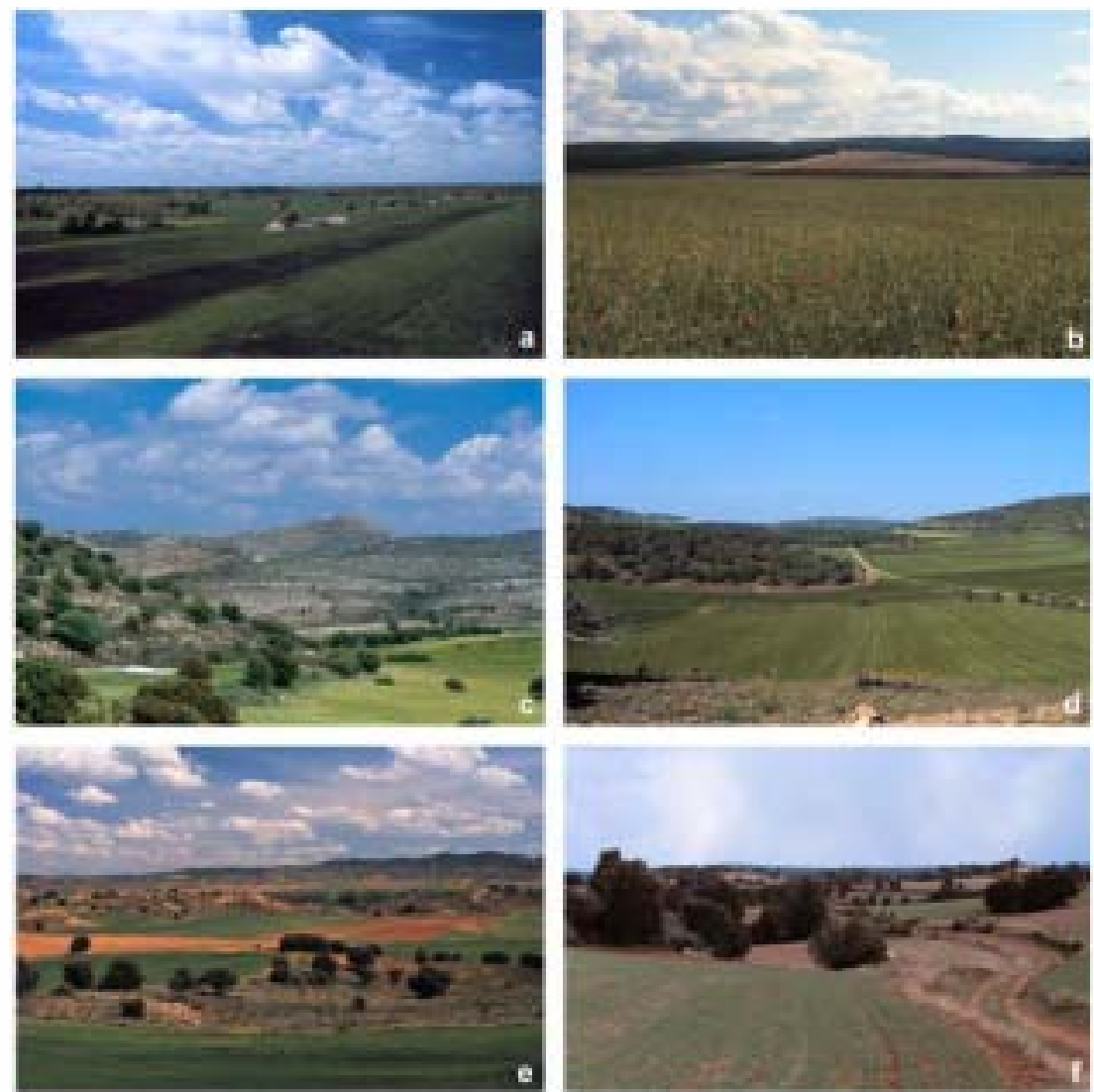

gional landscapes, it is essential to begin with the geological factors that underlie and condition nearly all others.

The flat, high, stony, dry plateaux, where groundwater levels are deep, are examples of the inter-relationship between geotic, biotic and anthropic factors. In these areas, either coniferous (the more humid areas of western slopes) or scarce oak forests (warm areas of southern slopes) develop. This semi-natural plant cover is even more altered near historically important villages, where deforestation for grazing has produced seasonal prairies and steppe covered by aromatic plants and occasional sabine forests (presently highly valued) (e.g. the Cobeta pasture and the Torremocha sabine forest). These are mapped in the same category.

The wide valleys, generally over less cohesive rock bodies, show great homogeneity in their components. Hydrologically fertile and mechanically more favourable for agriculture, they sustain intense cereal cultivation. The most important villages are on their slopes.

The greatest complexity is observed in areas which are termed 'hybrid orographies' (with concave and convex features). Generally, these are Neogene or older Quaternary erosive palaeo-surfaces, very degraded by intense erosion related to the Plio-Quaternary entrenchment of the fluvial network. These are regions where fluves and inter-fluves coexist, and where these show great variety in size, height, and relative proportion (from surface predominance of valleys on the interfluves to just the opposite). The extent of their associated lands and their mechanical properties, their proximity to populated areas, and historical and local factors, have together conditioned the intensity and type of agriculture sustained.

At a second level of classification, several subdivisions for each of these types can be established (Figs. 5, $6,7,8$, 9, Table 1). Landscapes of convex forms are composed either of residual reliefs developed on Neogene planation surfaces, or originated by exhumation of pre-Miocene reliefs. The following subdivisions can be further differentiated (Table 1):

Paleozoic Sierras consist of large uplands of shales and quartzites (Table 1). These stand out at regional level and produce wild, dark landscapes generally covered by forest or scrub (Fig. 7a, b). They are found only on Palaeozoic rocks with deformation structures characteristic of the middle structural level.

Triassic slopelands and cuestas are composed of brown limestones or red sandstones with terraces (Table 1). They are covered by forest, scrub or steppe with aromatic plants, and are developed on Lower Triassic (Fig. 7c) and Lower Jurassic rocks in areas with simple and monoclinal tectonic structure. 
Jurassic and Cretaceous mounts are generally flat topped and other calcareous hills, in most cases, generally with cultivated, earthy pedestals (Table 1). These are found on Lower Jurassic and Cretaceous (Fig. 7d) marly sandy or calcareous successions in areas with sub-planar to undulated structure.

Mounts and cuestas are minor forms than only stand out locally or as isolated points (Fig. 5). These produce defined landscapes or other types of visual attentionattracting landscapes.

Three types of visual landscape can be distinguished within the plains and flat relief group (Table 1). They are landscapes inherited from Neogene and Quaternary planation surfaces, barely degraded or non-degraded by Plio-Quaternary erosion:

Jurassic plateaux are calcareous and heterogeneous plains, generally covered by steppe with aromatic plants and with forested areas (Table 1). These are usually developed on calcareous successions of Lower Jurassic material of any tectonic structure (Fig. 7e, f).

Neogene plains are earthy, homogeneous plains, largely cultivated but with forest areas (Table 1). These are developed on Upper Neogene sedimentary successions with sub-horizontal bedding (Fig. 8a).
Plio-Pleistocene piedmonts are inclined, ahnost horizontal surfaces, generally with an extensive agricultural use (Table 1). These are developed on PlioPleistocene alluvial conglomerate platforms with no tectonic structure (Fig. 8b).

The landscape structure group herein referred to as 'hybrid forms' (Table 1) includes territories characterised by their convex and concave elements, but with orographic and visual cohesion. They usually originate as a spatial transition from plains to valleys and correspond to an intermediate stage of development.

Jurassic and Cretaceous ridges and valleys are of wild nature (Table 1), largely covered by forest, scrub or steppe with aromatic plants. These are found close to large concave structures on Lower Jurassic or Upper Cretaceous homogeneous calcareous successions in tectonically folded areas (Fig. 8c).

Jurassic and Cretaceous hills and floodplains are of smooth configuration, covered by steppe with aromatic plants and extensive cereal cultivation, respectively (Table 1). These are seen near large flat structures on Lower Middle Jurassic or Cretaceous heterogeneous successions of limestones, marls and sands, in areas that are tectonically undulated (Fig. 8d).
Fig. 9 Views of concave landscapes described in text (see Fig. 6 for location and orientation): a Narrow valleys, Dulce canyon (Pelegrina) from the road to Sigüenza, view towards W. UTM 531-4540; b Narrow valleys, Gallo gorge (Corduente) from the La Ermita vantage point, view towards ESE. UTM 585-4520; c Wide valleys, Dulce river valley (Pelegrina) from the road to Sigüenza, view towards WSW. UTM 53-4541; d Complex valleys, Podanco river plains (Palazuelos) from Palazuelos, view towards NNW. UTM 525-4551; e Dales, Las Navas from the road to Zaorejas, Torremocha del Pinar, view towards NW. UTM 580-4527; f Dolines, Siete Hoyos (Sagides), view towards NW. UTM 559-4554
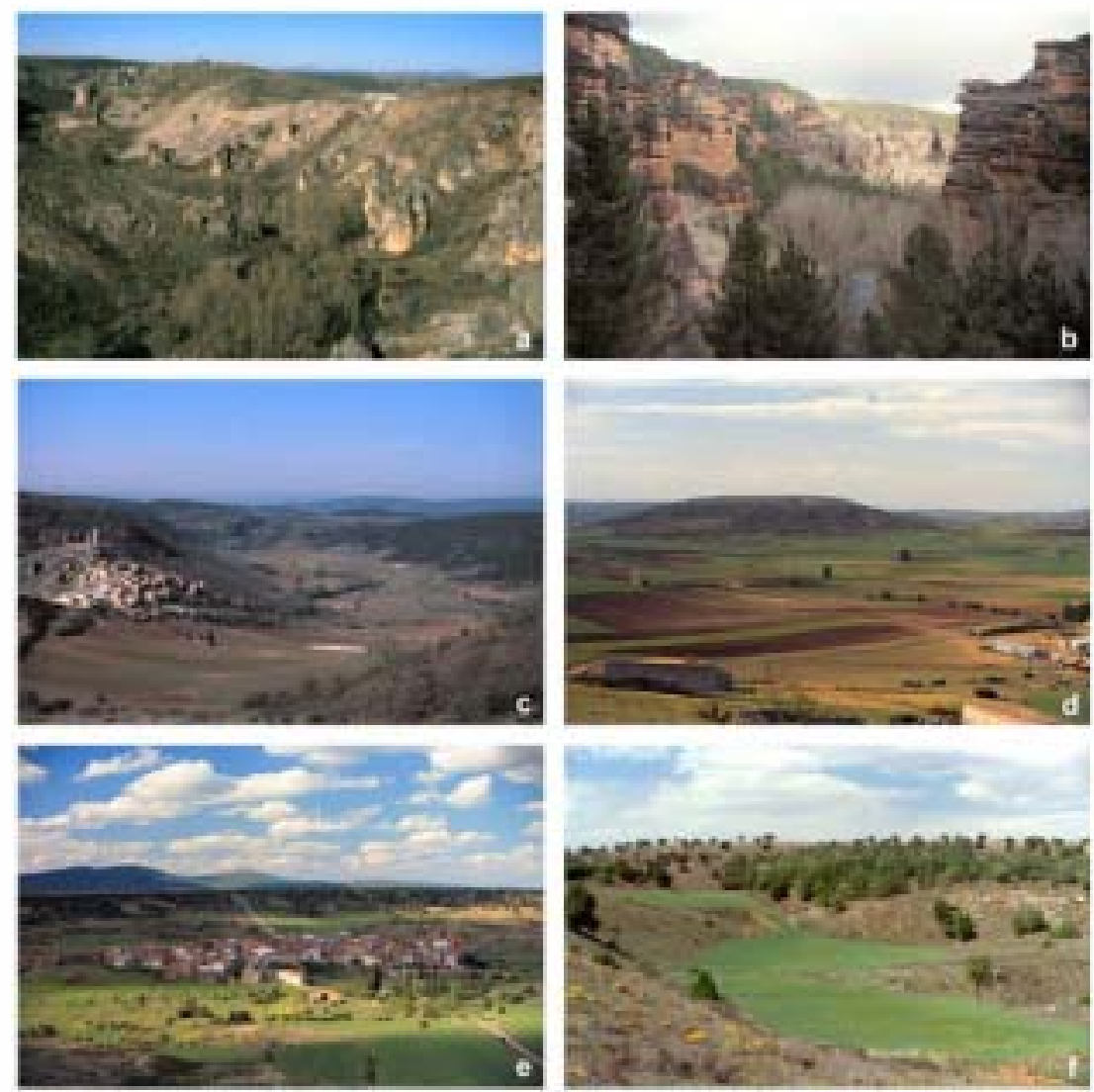
Cainozoic rolling plains, with different types of agricultural use and areas with spontaneous vegetation (Table 1). These are irregularly distributed and found on Cainozoic clay (predominantly brown) sediments with no tectonic structure (Fig. Be, f).

Finally, concave structures (Table 1) include all the elements generated by post-Pliocene fluvial erosion, provided they can be distinguished visually:

Narrow valleys are generated by recent entrenchment of the fluvial network on cohesive rocks (Table 1). These are located on red terrigenous material of the Lower Triassic or greyish-blue Jurassic and Cretaceous calcareous material (Fig. 9a). These landscapes have abundant rock and wild vegetation predominates over agricultural use (Fig. 9b).

Wide valleys (Table 1) are developed mainly because of the greater erosion rate of the less cohesive rocks. These are found on Upper Triassic red clays, Lower Jurassic beige marls, Lower Cretaceous white sands and Tertiary yellowish and orange terrigenous material. These landscapes have well-developed, cultivated, fertile flood plains and hillsides with mainly spontaneous plant cover (Fig. 9c).

Complex valleys with hills (Table 1) appear out of the confluence of several very evolved wide valleys and are found exclusively on Upper Triassic red clays in areas with sub-horizontal tectonic structure (Fig. 9d). These landscapes are very wide with visual lines that are not constrained to the orientation of the linear vallevs.

Other small valleys (Table 1) (dales, ravines, watercourses, dolines) and other concave forms of smaller dimensions. These are small landscapes within the previous structures (Fig. 9e, f).

This organization can be extended further to include a third classification expanding on the detail of these observations and descriptions and establishing new landscape types. This has already been performed for some local areas (Garcia-Quintana et al. 2000), but it is not developed in this study.

\section{Conclusions}

In the Sigüenza Molina de Aragón region, methods commonly used in regional geological analysis allow an exhaustive knowledge of the origin of landscapes to be obtained. These data-cartographic and photographic - are a basic and indispensable tool for landscape assessment, protection and management.

The most outstanding orographic components are flat areas. The valleys of a very entrenched (some $150 \mathrm{~m}$ on average) fluvial network cut this compact orographic structure in a highly irregular manner. The lithological composition and tectonic structure of this region are major factors in the shaping of the natural environment. Land properties, such as coloration and agricultural capacity, are controlled by these geological characteristics. The latter are of the greatest importance in the area's landscapes as the distribution of the different types of plant cover is clearly related to the ploughabilty of the soil. Other important factors are climate and anthropic uses. Together, these four factors determine the region's landscapes. At least at regional level, not all combinations of geotic, biotic and anthropic factors exist. The geological factors condition the inter-related biotic and anthropic factors. The concurrence of factors produces visually identical landscapes.

A classification of regional landscapes based on the above four agents is possible. The main shaping agents are the geological agents, and these are used as the first determining criterion. The first level distinguishes predominantly flat, concave or convex areas. Other parts of the territory are, however, composed of concave and convex combinations that originate hybrid orographic structures. At the second level of classification, several subdivisions for each of these types can be established.

Acknowledgements This work includes some of the results obtained in Project PR3/4-12421 of the Universidad Complutense de Madrid, and Project CGL2004-02179BTF of the Dirección General de Investigación (Ministerie de Educación y Ciencia). The authors wish to thank Adrian Burton for his help with the English.

\section{References}

Al Bakri D (2001) Towards developing a geoscientific approach to sustainable agricultural and rural development. Environ Geol 40:543 555

Aoki Y (1999) Trends in the study of the psychological evaluation of landscape. Landsc Res 24:85 94

Bailey RG (1996) Ecosystem geography Springer, Berlin Heidelberg New York
Barettino D, Gallego E (1996) Cartografía del paisaje. In: Manual de procedimientos. Plan nacional de cartografia temática ambiental. Instituto Tecnológico Geominero de España, Madrid

Bertrand G, Berutchachvili N (1978) Le Géosysthème ou systhème territoriel naturel. Revue Géographique des Pyrénées et du Sud-Quest 49:167 180

Bloom AL (1969) The surface of the Earth. Prentice-Hall, New Jersey
Bourne R (1931) Regional survey and its relation to stock-taking of the agricultural and forest resources of the British Empire. In: xford forestry memoir 13. Clarendon, Oxford

Burbank DW, Printer N (1999) Landscape evolution: the interactions of tectonics and surface processes. Basin Res 11:1 6

Christian CS (1958) The concept of land units and land systems. In: Proceedings of the 9th Pacific Science Congress $20: 7481$ 
Estébanez Álvarez JG, Molina Ibáñez M, Panadero Moya M, Pérez Sierra C

(1991) Castilla La Mancha. In: Bosque J, Vila J (eds) Geografía de España, vol 7. Planeta, Madrid, pp 158333

Fairbanks DHK, Benn GA (2000) Identifying regional landscapes for conservation planning: a case study from KwaZulu-Natal, South Africa. Landsc Urban Plan 50:237 257

Fenneman NM (1916) Physiographic divisions of the United States Plate I. Ann Assoc Am Geogr 6:1898

García-Quintana A, González-Martín JA, Martín-Duque JF, García-Hidalgo JF (2000) Los paisajes de la región de Mihnarcos: sistemática y cartografía (Cordillera Ibérica, Provincias de Guadalajara, Soria y Zaragoza). Geotemas 1:249 253

García-Quintana A, García-Hidalgo JF, Martin-Duque JF, Pedraza J, González-Martin JA (2004) Geological factors of the Guadalajara landscapes (cen Spain) and their relevance to landscape studies. Landsc Urban Plan 69:417 435

Godfrey AE (1977) A physiographic approach to land use planning. Environ Geol 2:43 50

Gómez de Mendoza J, Mata Olmo R, Sanz Herraiz C, Galiana Martín L, Manuel Valdés CM, Molina Holgado P (1999) Los paisajes de Madrid: naturaleza y medio rural. Alianza Editorial, Madrid
Guzzetti F, Reichenbach P (1994) Towards a definition of topographic divisions for Italy. Geomorphology 11:57 74

Host GE, Polzer PL, Mladendoff DJ, White MA, Crow TR (1996) A quantitative approach to developing regional ecosystem classifications. Ecol Appl 6:608 618

Howard JA, Mitchell CW (1980) Phytogeomorphic classification of the landscape. Geoforum 11:85 106

King C (1878) United States geological exploration of the 40 th parallel, annual reports to the secretary of war, $8 \mathrm{vol}, \mathrm{pp}$ 18711878

Laurie M (1975) An introduction to landscape architecture. Pitman, London

Linton DL (1951) The delimitation of morphological regions. In: Stamp LD, Wooldrige (eds) London essays in geography. Longmans, London

Martín Duque JF (1997) La Geomorfología en los estudios del medio físico y planificación territorial. Propuesta metodológica y aplicación a un sector del Sistema Central. PhD Thesis, Universidad Complutense, Madrid

Martín de Agar P, de Pablo CL, Pineda FD (1995) Mapping the ecological structure of a territory: a case study in Madrid (Central Spain). Environ Manage 19:345 357

Moss MR, Nickling WG (1980) Landscape evaluation in environmental assessment and land use planning. Environ Manage 4:57 72
Nikolayev VA (1973) Principles of a landscape classification. Vestnik Moskovskogo Universiteta, geografiya 6:30 35

Omernik JM (1987) Ecoregions of the conterminous United States. Ann Assoc Am Geogr 77:118 125

Pain CF (1985) Mapping of landforms from Landsat Imagery: an example from eastern New South Wales, Australia. Rem SensEnvir 15:55 65

Pedraza J, Gonzalez Alonso S, Centeno JD (1986) Mapa fisiográfico de Madrid. Comunidad de Madrid, Madrid

Powell JW (1875) Physical features of the Colorado Valley, I Mountains and Valleys. PopSci Month 7:384 399

Sochava VB (1972) L'Étude des gèosysthèmes. Stade actuel de la Géographie physique complexe (Translated to French by CL Rondeau, CNRS Centre de Documentation et cartographie géographique, Paris). Izvestija Akademii Nauk SSSR, Serija Geografisceskaja $3: 1821$

Terkenli TS (2001) Towards a theory of the landscape: the Aegean landscape as a cultural image. Landsc Urban Plan 57:197 208

Wheeler GM (1889) United States geographical surveys west of the one hundredth meridian, Washington Final Reports I-VII

Wright RL (1972) Principles in a geomorphological approach to land classification. Z Geomorph NF 16:351 373 